\title{
Towards the Highest and Best Use of Residential Lands in Low and Medium Density Estates in Lagos
}

\author{
Adebayo, Michael Adedayo PhD. \\ Department of Estate Management, Federal University of Technology, Akure \\ Email: dayoadebayo2006@yahoo.com \\ Oladapo, Rashidat Adejoke PhD. \\ Department of Estate Management, Federal University of Technology, Akure
}

Doi:10.5901/ajis.2014.v3n6p21

\section{Abstract}

The study focuses on the highest and best use of residential lands in low and medium density estates in Lagos. Two residential estates: Ikeja GRA (low density) and Ajao Estate, Isolo (medium density) are purposively selected as case study. A total of 383 structured questionnaires administered on landlords were used to elicit information on the land and buildings in the Estates. The data collected were analysed with the aid of Multiple Linear Regression. The study found that accommodation units and building type are the significant factors to consider in achieving the highest and best use in low density residential estates. In medium density estates, accommodation units, land cost, plot size and building cost are the factors to consider. Land owners in residential estates are therefore, advised to consider these factors for highest and best use of their lands.

Keywords: Highest and best use, low density, medium density, residential estates, Lagos.

\section{Introduction}

The highest and best use of land for sustainable development requires that the use of land and its resources be harmonious with respect to physical, social, economic and institutional settings. For efficient use of land, the physical setting must be considered. This defines the natural environment in which man finds himself and with the nature and characteristics with which he must work. The physical setting determines the total supply of land resource upon which the volume of human demands for its use is based. The physical environment has to be planned to provide easy communication and transportation, residential, commercial and industrial layouts, parks, playground, schools, shopping centres, open spaces, water, electricity, drainage, security and other hosts of facilities and services that make the city liveable. Agbola (1994) argues that it is only through development control, which comprises land use zoning and enforcement of planning standards that the ultimate aim of physical planning for effective use of urban land could be achieved. This aim is to achieve a healthy, conducive, satisfying and aesthetically pleasing environment on which to pursue different kinds of human activities.

The use of residential land must also consider and conform to the social norms or widely held beliefs of the people. For sustainability, attention should be given to social factors such as the culture and tradition, standard of living and moral value.

Economic consideration has great impact on the allocation of land to different uses. This is because; individuals and groups will always seek to make profitable use of their land resources. For efficient use of land resources, however, the economic consideration should be in balance with the physical, social and institutional settings.

The institutional setting is concerned with the roles that the cultural environment and communal forces play in influencing man's use of land. All land developments must be legal and comply with laws, ordinances and regulations.

On the other hand, inefficient urban land use that is, the consumption of a lot of land for each person causes more urban land loss than is necessary for attractive, economically vibrant cities (Sokolow, 2006). Development that spreads out over the land also leads to more traffic, energy consumption and air pollution, while increasing the cost of providing basic public services like water and sewers, police and fire protection. Sokolow (2006) concludes that indeed, the efficiency of development is really the key challenge for cities that want to preserve their land resource and their quality of life. This assertion is buttressed by Zongheng's (2006) view that "if China does not tighten up land management, more 
than 90 percent of Shenzhen city land will be used up in four years, and the water and electric power consumption will be three times more than it was in year 2006, the economic growth will not be sustainable if the city fails to rein in wasteful use of land resource; land must be used efficiently."

In the light of the preceding statements and in view of the relatively fixed physical supply of land coupled with ever increasing population of urban centres demanding for land for residential and other uses, it becomes imperative to undertake a study on the highest and best use (HBU) of residential lands in Lagos metropolis.

\section{The Highest and Best Use of Urban Land}

Some land economists such as Barlowe (1986) argue that there may be two alternative highest and best uses for a particular property. One highest and best use is market derived or economic in nature and is the concept traditionally applied by valuers. In addition, there may be a social or community derived 'highest and best use' for a property. Barlowe uses the example of a forest which alternatively could be either cut down or retained. From the landowner's point of view, cutting the forest may clearly be the highest and best use in economic terms. This may bring the property owner into conflict with environmental groups that promote a 'social highest and best use' of the property that requires that the forest be retained.

The correct definition of highest and best use has been a source of debate in real estate circles. Graaskamp (n.d) in Nalikies (2003) for example argued that highest and best use analysis should seek to incorporate or accommodate the reality of community politics. Moreover, town-planning controls may have significant impacts on the property development process and that in many instances, the optimum or most profitable development may be the one that takes the line of least resistance in terms of recognizing the concerns of the public. In terms of New Zealand valuation methodology, ' highest and best use' is defined in the New Zealand Institute of Valuers Technical Handbook - NZIV (1995) as: the most probable use of an asset which is physically possible, appropriately justified, legally permissible, financially feasible, and which results in the highest value of the asset being valued.

Highest and best use is an economic concept and as all market-driven development is time-sensitive. According to Sevelka (2004) a bonafide developer has no use for land that cannot be immediately subdivided and "it is extremely rare for buyers to accept more than minimal risk when the contemplated use of a property involves legal condition e.g. rezoning or a physical condition (Lennhoff and Parli, 2004).

"Real Estate Appraisal Terminology" defines highest and best use as "that reasonable and probable use that supports the highest present value, as of the effective date of the appraisal. Alternatively, that use, from among reasonably probable use and legal alternative found to be physically possible, appropriately supported, financially feasible which results in highest land value. This definition applies specifically to the highest and best use of land. It is to be recognized that in cases where a site has existing improvement, the highest and best use may very well be determined to be different from the existing use. The existing use will continue, however, unless and until land value in its highest and best use exceeds the total value of the property in its existing use. To explain further, because the use of land can be limited by the presence of improvement, highest and best use is determined separately for the land or site as though vacant and available to put to its highest and best use and for the property as improved. The first determination (highest and best use of land as though vacant) reflects the fact that land value is derived from potential land use. The second determination (highest and best use of property as improved) refers to the optimum use that could be made of the property considering the existing improvements. The highest and best use of the improved property may or may not be the same as the highest and best use of the site.

\section{The Study Area}

Metropolitan Lagos is located within Lagos State in the south-western part of Nigeria. It is located approximately on latitude $6^{\circ} 22^{\prime} \mathrm{N}$ and $6^{\circ} 52 \mathrm{~N}$ and longitude $2^{\circ} 42^{\prime} \mathrm{E}$ and $3^{\circ} 22^{\prime} \mathrm{E}$ (Odumosu, 1999). Metropolitan Lagos consists of 16 urban local governments out of the 20 local government areas in Lagos State (World Bank, 2005; FGN, 2007). They are Apapa, Ajeromi-Ifelodun, Alimoso, Agege, Amuwo-Odofin, Etiosa, Ifako-ljaiye, Ikeja, Kosofe, Lagos Island, Lagos Mainland, Mushin, Ojo, Somolu and Surulere. Lagos population according to the National Population Commission (2006) is 9.2 million. This figure is, however, being disputed by the Lagos State Government which claimed to have recorded a figure of about 18 million from a parallel census enumeration carried out.

A field survey conducted in 2001 shows that undeveloped land in Lagos metropolis amounted to less than 30 percent (Babade, 2003). Now more than ever, one can clearly see the unprecedented lateral expansion of Lagos veering 
alarmingly out of control. The pace of development has now pushed the boundaries of urban Lagos beyond the borders of Lagos State well into neighbouring Ogun State. Residential areas occupy the single largest proportion of 8,939 hectares (51.9\%), commercial 821hectares (4.8\%), industrial 1,444heactares (8.4\%), institutional and special use 2,366 hectares (13.7\%), open spaces 453 hectares (2.6\%) and transportation 3,205 hectares (18.6\%) (Oduwaye \&Dekolo, 2007). The population growth rate of Lagos has serious implications on the trend of urban residential land use development. There is a high demand for residential land as dictated by high demand for housing. The non-availability of sufficient land and lack of easy access to land have led to a rise in land prices. The nature of water bodies in and around metropolitan Lagos has great influence on the nature of land development thus constituting tremendous constraints on physical development.

\section{Research Methods}

The population of this study comprises two selected residential estates of low and medium densities within Lagos metropolis. The purposive sampling method helps to choose the estates that adequately represent all the estates in each density. In this wise, Ikeja GRA, (low density) and Ajao Estate-Isolo, (medium density) are chosen. These estates are chosen due to their unique characteristics in terms of density, geographical location and ownership. The structured questionnaires administered on the landlords in the studied estates are to elicit information on the type of building, accommodation units, plot size, land cost, accessibility and demand for such type of building. The population, sample size and the retrieved questionnaires for each estate are shown on Table 1. Multiple regression analysis is employed to analyze the data.

\section{Results and Discussion}

The summary of questionnaire administration is presented on Table 1. It shows the number of questionnaires distributed and returned in each of the estates. The percentage response is computed accordingly.

Table 1: Questionnaire Distributed To Respondents

\begin{tabular}{lccc}
\hline Estates Pop. & $\begin{array}{c}\text { Questionnaire } \\
\text { Administered }\end{array}$ & Questionnaire Returned & Percentage Response \\
\hline Ikeja GRA 723 & 258 & 155 & 60 \\
Ajao Estate 1942 & 335 & 228 & 68 \\
Total 2665 & $\mathbf{5 9 3}$ & $\mathbf{3 8 3}$ & $\mathbf{6 5}$ \\
\hline
\end{tabular}

Source: Author's research design, 2012.

Table 1 shows that a total of 593 questionnaires were administered in the studied estates while 383 were returned and found useful for analysis. The overall percentage response was $65 \%$. This was considered large enough and hence used for the study.

\section{The Highest and Best Use of Residential Lands in Lagos}

In an attempt to achieve the highest and best use of residential lands in Lagos this study looks at the following variables namely: annual rental value, building type, accommodation units, zoning regulation, land cost, plot size, accessibility, building cost, market competition and demand as they affect the HBU of lands globally. These variables are premised upon earlier works of Boddy (2002), Goldstein and Goldstein (2004) and Tideman (2006). The Multiple Linear Regression Analysis is used to determine the contribution of each of the variables to the Highest and Best Use of residential lands as developed. Moreover, the analysis helps to know which of the variables made the greatest contribution. The regression analysis was conducted by employing SPSS16 computer software package. The generic equation of multiple regression models upon which the resultant model is based is given as:-

$Y=\beta_{0}+B_{1} X_{1}+B_{2} X_{2}+B_{3} X_{3}$ $\mathrm{B}_{9} \mathrm{X}_{9}+\mathrm{e}_{\mathrm{i}}$ 12

Where $Y=$ Annual Rental Value as proxy for HBU

$\mathrm{B}_{0}=$ Constant

$\mathrm{B}_{1}-\mathrm{B}_{9}=$ Coefficients of regression 


$$
\begin{aligned}
& X_{1}=\text { Building type } \\
& X_{2}=\text { Accommodation } \\
& X_{3}=\text { Zoning Regulation } \\
& X_{4}=\text { Land cost } \\
& X_{5}=\text { Plot size } \\
& X_{6}=\text { Accessibility } \\
& X_{7}=\text { Building Cost } \\
& X_{8}=\text { Demand } \\
& X_{9}=\text { Market Competition } \\
& e_{i}=\text { error term }
\end{aligned}
$$

Table 2: Results of Regression Analysis on Variables Determining HBU in Low Density Estates

\begin{tabular}{lccccc}
\hline & $\begin{array}{c}\text { Unstandardized Coefficients } \\
\text { B Std. Error }\end{array}$ & $\begin{array}{c}\text { Standardized Coefficient } \\
\text { Beta }\end{array}$ & t-value & Sig. \\
\hline Constant & 2.492 & 1.522 & & 1.638 & .104 \\
Building Type & $-.845^{\star}$ & .129 & -.326 & -6.534 & .000 \\
Accommodation & $.793^{\star}$ & .036 & 1.082 & 21.895 & .000 \\
Zoning Regulation & -.065 & .516 & -.004 & -.126 & .900 \\
Land cost & .010 & .013 & .072 & .771 & .442 \\
Plot size & .000 & .001 & .052 & .588 & .558 \\
Accessibility & -.361 & .269 & -0.048 & .1 .340 & .182 \\
Building cost & .004 & .013 & .012 & .296 & .768 \\
Demand & -.181 & .259 & -.027 & -.698 & .486 \\
Market competition & .747 & .421 & .071 & 1.775 & .078 \\
Df & 9 & & & .000 \\
F-value & $84.541^{*}$ & & & & \\
R & .840 & & & & \\
Adjusted R & .830 & & & & \\
\hline
\end{tabular}

Source: Analysis of survey Data, 2012 * Significant at 0.01 level

The R-square statistic of the model is 0.84 while the adjusted $\mathrm{R}$ square is 0.83 . Hence, the coefficient of determination of the model is $84 \%$. This shows the contribution of all the independent variables to the dependent variables i.e. annual rental value. The value implies that $84 \%$ variation (changes) in annual rental value can be explained by the joint contribution of all the independent variables while only $16 \%$ variation in annual rental values is attributable to other external factors. The analysis of the variance shows the level of significance attached to the coefficient of determination. The computed $\mathrm{F}$ statistic ( $\mathrm{F}=84.541)$ falls in the rejection region, signifying that at least one of the model coefficients is non-zero. Therefore, the model appears to be useful for predicting the highest and best use of low density residential estates in Lagos since the coefficient of determination is high and significant. From the regression coefficient result, the significant determinants of highest and best use of low density residential estates are building types and accommodation units. In other words, the two major determinants of highest and best use of low density residential lands as developed in Lagos are the types of building and accommodation units in each building. Type of building is very germane to the rent chargeable on property and hence the value of such property. All things being equal, the rent chargeable on a tenement bungalow of "face me I face you" cannot be the same with that of a block of flats, duplex or a detached house. In the same vein, the number of accommodation units in a building affects the rent chargeable on such building. A five-bedroom detached house will command a higher value than a three-bedroom of same type 'ceteris paribus'. 
Table 3: Results of Regression Analysis on Variables Determining HBU in Medium Density Estates

\begin{tabular}{lccccc}
\hline & $\begin{array}{c}\text { Unstandardized Coefficients } \\
\text { B Std. Error }\end{array}$ & $\begin{array}{c}\text { Standardized Coefficient } \\
\text { Beta }\end{array}$ & t-value & Sig. \\
\hline Constant & .254 & .563 & & .451 & .653 \\
Building Type & .018 & .047 & .018 & .385 & .701 \\
Accommodation & $.124^{\star *}$ & .009 & .675 & 13.298 & .000 \\
Zoning Regulation & -.060 & .191 & -.012 & -.315 & .753 \\
Land cost & $-0.88^{\star *}$ & .026 & -.208 & -3.319 & .001 \\
Plot size & $.002^{*}$ & .001 & .158 & 2.552 & .011 \\
Accessibility & -.036 & .132 & -.011 & -.271 & .787 \\
Building cost & $.060^{\star *}$ & .009 & .275 & 6.332 & .000 \\
Demand & .135 & .109 & .053 & 1.241 & .216 \\
Market competition & -.047 & .076 & -.025 & -.615 & .539 \\
Df & 9 & & & & \\
F-value & $55.44^{* *}$ & & & & \\
R & .696 & & & & \\
Adjusted R & & & & &
\end{tabular}

Source: Analysis of survey Data, 2010

From Table 3, the regression analysis shows $\mathrm{R}^{2}$ as 0.696 . This indicates that $69.6 \%$ of the sample variation in annual rental value is attributable to the predictor variables. The model also shows that accommodation explains $67.5 \%$ variation while building cost accounts for $27.5 \%$ of the variations in annual rental value. The F-value ( $F=55.448)$ is highly significant at 0.01 level of significant. Other significant factors determining highest and best use in medium density estate include land cost and plot size. The statistical significance of accommodation variable in the regression analysis shows the importance of this variable in the determination of annual rent of any property. The number of accommodation units in a building determines the amount of rent to be paid if all other factors are kept constant. The larger the number of accommodation units, the higher the rent to offer. A smaller number of units will only command a lower amount of rent. The significance of building cost and land cost in the analysis can also be explained by the attitude of a prudent investor who might not let nor sell his property lower than what it cost him to build. In other words, the return expected from an investment of high cost- outlay would be higher compared to an investment of a smaller cost-outlay. If the cost of the land is high, the probability is high that the development on it would also be of high profile. The size of the plot is also statistically significant in the medium density estate based on the fact that the price of land is on the basis of per square meters. Hence, a large plot of land will command a high price as a result of size rather than any other factor.

\section{Conclusion and Recommendation}

The result of the study shows that in low density estate, the two major determinants of HBU are accommodation units and the type of building. The determinants of HBU in medium density estates are accommodation, land cost, plot size and building cost.

Land values in Lagos are very high and the resource has to be efficiently used. When land is used for that purpose which brings the relative maximum productivity, it is said to be the highest and best use. To achieve this, property investors in low density estates should consider the type of house to develop and the number of accommodation units to be provided in the property. For a given type of housing within a neighbourhood, the higher the number of accommodation, the higher the rental and capital values, all things being equal. In a medium density estate, it is proposed that a developer should consider the number of accommodation units in the property, the cost of the land, the size of the plot and the cost of the building to achieve the highest and best use of the land.

\section{References}

Agboola, T. (1994) "The Politics and Administration of Housing Standards and the Structure of Nigerian Cities." Urban Management and Urban Violence in Africa. Vol. 1, FRA, Ibadan.

Babade, T. (2003). Access to Urban Land in Nigeria: An Analysis of the Activities of Lagos State Land Use and Allocation Committee in 
Omirin et al. eds. Land Management and Property Tax Reform in Nigeria. Proceedings of a National Workshop organized by the Department of Estate Management, University of Lagos, Nigeria.

Barlowe, R. (1986) Land Resources Economics: The Political Economy of Rural and Urban Land Resource Use. Prentice Hall Inc., New Jersey.

Boddy, C. (2002) "Highest and Best Use. Back to the Land Mendocino Coast Real Estate Magazine. Htt;;//www.chetboddy.com/ highestbest.html

Federal Republic of Nigeria Official Gazette (2007): Legal Notice on Publication of the Details of the Breakdown of the National and State Provisional Total, 2006 Census (PDF), Retrieved on 2008-10-29.

Goldstein, M. R. and Goldstein, M. J. (2004) Highest and Best Use: Economic Feasibility. Goldstein, Goldstein, Rikon and Gottlieb, P.C. New York.

Lennhoft D. C. and Parli R. L. (2004). A higher and better definition. The Appraisal Journal (Winter) 45 - 49.

Nalikies B. (2003). Heritage Protection - Redefining Highest and Best Use? Presented at the Pacific Rim Real Estate Society $8^{\text {th }}$ Annual Conference, Christ Church, 21 - 23 January.

New Zealand Institute of Valuers (1995). Technical Handbook. Wellington: NZIV.

Oduwaiye L. and Dekolo S. O. (2007). Land Values in Low Density Residential Neighbourhoods of Metropolitan Lagos. Journal of Geography, Environment and Planning, 3(2), 50-68.

Sevelka T. (2004). When is subdivision the highest and best use? The Canadian Appraiser.

Sokolow, A. J. (2006) "Efficiency of Urban Development. American Farmland Trust.http://www.farmland.org/development efficienty1.html Tideman, N. (2006) Achieving Economic Efficiency of Land Use: The Case for Taxing Land. http://www.google.com

Zongheng, Xu (2006) "Shenzhen to Raise Land Use Efficiency". Shenzhen Daily June 23. 